\title{
Influential Factors for the IT Investment Decision Making Quality :An Empirical Study Focus on IT Governance
}

\author{
Ju-Yeon Ham \\ Department of MIS \\ Korea University Business School, Seoul, Korea \\ Jung-Hoon Lee \\ Graduate School of Information \\ Yonsei University, Seoul, Korea \\ Hyeok-Jun Woo \\ Graduate School of Information \\ Yonsei University, Seoul, Korea
}

\begin{abstract}
In recent years, many leading corporations are actively adopting IT as competitive resources to improve productivity and processes efficiency with strategic alignments. In effect, IT investment also continues to increase. As a vast growth of IT investment, questions and criticism on recent IT investment results are also rapidly being raised. Especially, improper decision making and management on IT investment may cause negative impact on the company's reputation and finances, therefore companies need reasonable and wise investment decision making on new IT projects. This study applies the conceptual framework of IT governance to IT investment decision making cases to examine how IT investment governance influences the quality of IT investment decision making and how business-IT strategic alignment affects the quality of IT investment decision making. This paper contributes to identify the main factors for reasonable and effective IT investment decision making and expected to provide proper guidelines for IT investment decision making.
\end{abstract}

Keywords: IT Investment Decision Making, IT Investment Evaluation, IT Governance, Business-IT Strategic Alignment, Relational Mechanism

\section{INTRODUCTION}

With fast growth in recent IT industry, many leading companies in and outside the country are actively adopting IT as the core resources to maintain their positions in the market and improve competitive advantage while continuing investment in IT [24].

Gartner [19] reported that IT industry will growth with 2010 IT spending forecast to toal $\$ 3.3$ trillion, a 3.3 percent increase from 2009. Standish Group [45], however, reported that $83 \%$ of IT projects did not generate economic effect as expected and over $50 \%$ including the cases of management failure after project completion showed failure. Such disappointing results in productivity and profit increase from IT investment are recently raising skepticism on IT investment [27]. Although demands for effective, reasonable IT investment decision

\footnotetext{
*Corresponding author. E-mail : comroi@naver.com Manuscript received Oct. 11, 2010 ; accepted Dec. 10, 2010
}

making are growing, it requires comprehensive measurement(evaluation), which can be very complicated, therefore many companies avoid IT investment evaluation or practice inefficient evaluation [7], [32]. For this reason, it is important for companies to understand IT investment evaluation clearly and to have proper foundation and practice for it [28].

However existing studies on IT investment focus only on the aspect of productivity of IT investment, which makes it difficult to find studies on the quality of IT investment decision making. Hence, this study attempts to identify main factors that affect the quality of IT investment decision making and the term 'the quality of IT investment decision making' used in this study implies 'effective decision making on a IT investment case'. In particular, IT governance can be interpreted as a strategic, systematic management method under co-existence of IT cost and the subsequent risks and the opportunity of additional values. IT governance includes identifying IT decision making system and the responsibilities for effective 
business-IT alignment; realizing strategic objectives of the organization; and maximizing business values [25]. The ultimate goal of IT governance is to realize business-IT strategic alignment for creating business values by IT investment.

This study, therefore, attempts to apply IT governance concept to IT investment decision making. It can provide proper guideline for reasonable, effective IT investment decision making.

The following questions are addressed in this study:

Q1: Does IT investment governance affect the quality of IT investment decision making significantly in decision making situations?

Q2: Does business-IT alignment especially affect the quality of IT investment decision making significantly in decision making situations?

The organization of the study to answer these questions is as follows: Section 2 includes theoretical background of the study through literature study; Section 3 explains the proposed research model and hypotheses development followed by definitions of the variables, measurements, data collection methods with demographic analysis. The next section suggest study results including analysis on validity of variables and reliability based on the collected resources and verification of the hypotheses; Finally, discussion of results, conclusion and academic and practical implications of the study to examine the limitations and the further direction of the study.

\section{LITERATURE REVIEW}

\subsection{IT Related Studies on Investment Decision Making}

There are various perspectives when defining IT investment [10]. One perspective is to view IT investment as technology investment and another is to view management information system as management/control cost [23], [54]. IT investment in this study includes related components such as applications, software, system software, hardware and human resources [44].

There have been many studies on IT investment, yet most of the studies focus on IT planning, such as evaluation or related measurement indexes; there are few studies on effective and reasonable IT investment decision making [40]. Studies on IT investment decision making have been carried out as the effect of IT investment in organizations has been recognized [14]. In particular, Earl [17] asserted that IT investment evaluation was the critical success factors for investment.

Bannister and Remenyi [1] suggest that various factors can affect IT investment decision making process and official, objective procedures, not subjective views from the decision makers, verification by exchanging opinions and collective perspective through these processes will lead to the most effective, reasonable decision making. Therefore effective, reasonable IT investment decision making can be defined as 'maximizing company profit and values by minimizing IT investment risks in overall aspects through IT investment decision making process'. In particular, IT Governance is a strategic, systematic IT management method for companies, which is a prerequisite for effective, reasonable IT investment decision making to clarify rights and responsibilities in IT investment decision making and to emphasis on clear, objective procedures [2].

\subsection{Literatures Review on IT Governance Research}

IT governance is a prerequisite for IT investment decision making and its concept was recognized to address issues on IT control and management [26]. Weill and Broadbent [53] reported that companies successful in IT investment showed approximatley $40 \%$ more investment than their competitors, indicating they suggested clear business strategies and the roles of IT in accomplishing the strategies; change in the organizations to maximizing the effect of new IT capabilities; and clear responsibilities and duties accordingly.

Especially the companies with the best results, unlike the ones with failure, practiced effective IT governance for successful strategic support. The study result implies that great IT governance system brings the companies better IT investment results.

Therefore this study redefines IT governance by considering overall aspects of IT governance as discussed earlier. IT governance is 'a means or a system that realizes business goals by using IT assets; and to accomplish companies' strategic goals by clear structure of decision making rights and responsibilities, systematic process and efficient relational mechanism'.

Furthermore, Van Grembergen [48] and; Weill and Ross [55] suggest three areas of IT Governance framework development: structures, processes and communication protocols or approaches. Peterson [38] also suggests that IT Governance can be established by combination of structure, process and relational mechanism. In here, structure includes personnel with responsibilities (duties) as IT managers or the members of IT committees. Process indicates strategic decision making and monitoring (e.g. IT balanced scorecard). Relational mechanism includes business/IT involvement, strategic dialogue, shared knowledge/learning and efficient communications. In particular, these are comprised of individual sub-systems, through which IT governance has overall, powerful effect; and requires holistic approach due to its complex and dynamic nature [16], [36], [43]. Therefore successful establishment of IT governance framework requires complex and comprehensive organization of structure, process and relational mechanism. In other words, different organizations require different combinations of structure, process and relational mechanism [11], [41]. In addition, IT Governance should endure constant evolution, development and change to survive through today's fastchanging, intense market competitions.

\subsection{Literatures Review on Business-IT Strategic Alignment}

Duffy [15] defined business-IT strategic alignment as "a process and its objective for companies to gain competitive advantage by maintaining and developing symbiotic relationship between business and IT". Business-IT alignment is not a new concept; it has been discussed with various models and related framework developments [4]. Henderson and 
Venkatraman [21] already developed strategic alignment model(SAM) in 1993 and many other researchers have further discussed on the concept [5], [8], [18], [29]-[31], [33], [36], [39], [46],[47]. The ultimate goal of the aforementioned IT governance is to realize strategic alignment between business and IT to guarantee business values through IT investment [12]. In other words, business-IT strategic alignment can be an important driving force that enables companies to create business values through IT investment [20].

The important thing here is how to achieve the ultimate goals of strategic alignment between business and IT. This study, therefore, is 'to draw effective, reasonable IT investment decision making' in a decision making situation, as stated prior to the ultimate goals of business-IT strategic alignment. It is 'to maximize company profit and values by minimizing IT investment risks in overall aspects through IT investment decision making process', which is possible by establishing business-IT alignment through Governance system in IT investment decision making [9].

\section{RESEARCH MODEL AND HYPOTHESES DEVELOPMENT}

\subsection{Proposed Research Model}

Based on the studies by Peterson [37], Van Grembergen and De Haes [49] and; Weill and Woodham [56], in which the strategic relationship for IT investment decision making can be enhanced through structure, process and relational mechanism of IT governance and systematic IT investment management(quality improvement of IT investment decision making) can be realized accordingly, this study is carried out based on the research model shown in Figure 1.

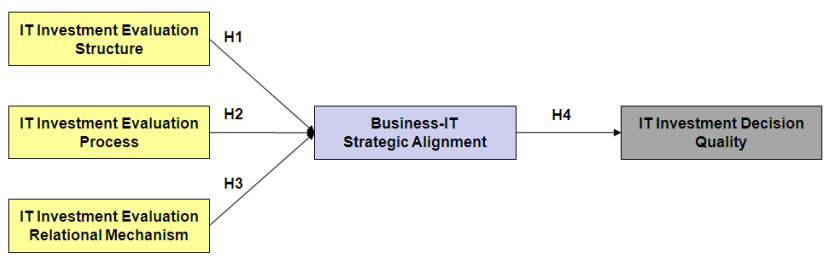

Fig. 1. Proposed Research Model

\subsection{Hypotheses Development}

As explained earlier, great IT governance system enables companies to draw great results from IT investment and effective IT governance brings successful strategic support and the outcomes [55]. Peterson [38], Van Grembergen et al. [48], Weill and Woodham [56] suggest that IT governance can be realized by combination of structure, process and relational mechanism [49] and optimal combinations of structure, process and relational mechanism may vary depending on situations of the companies [12]. By applying this idea to IT investment decision making, structure, process and relational mechanism for IT investment decision making can function as IT investment governance. Cumps et al. [9] reported that wellorganized IT investment governance system was important for business-IT strategic alignment. In particular, according to the study on practice and maintenance of business-IT strategic alignment by Luftman and Brier [30], the critical success factors of IT committee are communication with others, authority and responsibilities to practice decisions, business-IT partnership(relationship) and leadership and process to lead to the right direction.

The following hypotheses, therefore, can be suggested:

H1: The better IT investment decision making (IT investment evaluation) structure is established, the higher the level of business-IT strategic alignment will be.

IT governance process includes strategic decision making, SISP(Strategic Information Systems Planning), monitoring(e.g. IT BSC), modification and process frameworks [49]. SISP is a method widely applied for business-IT alignment [49]. A Canadian financial group established IT BSC to identify the causation among performance indicators and realized more efficient business-IT strategic alignment [52]. Continuous learning and establishing growth foundation are the main factors for achieving IT missions, which ultimately leads to effective IT governance by meeting business requirements [51]-[52]. It eventually leads to business-IT strategic alignment, the critical factor of IT governance, and to IT business values.

Therefore the following hypothesis is possible:

H2: The better IT investment decision making (IT investment evaluation) process is established, the higher the level of business-IT strategic alignment will be.

Another important IT governance mechanism includes effective both-way communication and proper relationship and establishment of effective partnership between business and IT [48]. Especially relational mechanism of IT governance enables combined use of proper structure and process to achieve and maintain business-IT alignment [49]. The mechanism includes business/IT participation, strategic dialogue, training, shared learning and proper communication [49]. Coughlan et al. [6] reported in their study on strategic alignment in terms of communication that better mechanisms of communication between IT divisions and other divisions were needed for better business-IT strategic alignment.

Therefore the following hypothesis is possible:

H3: The better relational mechanism of IT investment decision making (IT investment evaluation) is established, the higher the level of business-IT strategic alignment will be.

Despite complex, multilateral nature, business-IT strategic alignment is still important for creating IT business values and worth pursuing [22], [53]. Especially IT values for business are related to the level of business-IT alignment and the degree of meeting the expectations of the business organizations [22]. In this study, the ultimate goal of business-IT strategic alignment in IT investment decision making is defined as 'to draw effective, reasonable IT investment decision making'. In other words, it is 'maximizing company profit and values by 
minimizing IT investment risks in overall aspects through IT investment decision making process', which is possible by business-IT alignment through governance system in a decision making situation [9].

Therefore the following hypothesis is possible:

H4: The higher the level of business-IT strategic alignment is, the higher IT investment decision quality will be.

\section{RESEARCH METHODOLOGY}

\subsection{Measurement Development}

The operational definitions and measurements of the five independent variables used in this study are shown in table 1. Peterson [38], Van Grembergen et al. [50] and; Weill and Woodham [56] suggested that IT governance could be established by combination of structure, process and relational mechanism [49], all of which can be interpreted and applied in IT investment decision making as IT investment governance. IT investment evaluation structure (IES) in this study indicates 'the degree of organization of IT investment evaluation committee on the issues when IT investment decision making'; it identifies organization of the committee and roles of the members and measures the degree of responsibilities. IT investment evaluation process (IEP) indicates 'the progress of IT investment evaluation process in IT investment decision making'; it evaluates the appropriateness of IT investment evaluation process on the issues and its progress. IT investment evaluation relational mechanism indicates 'communication between the participating divisions and IT divisions in IT investment decision making'; it evaluates communication in work transaction.

Business-IT strategic alignment indicates 'consideration on the relationship between business strategies and IT strategies for IT investment'; it evaluates agreement and harmony of business strategies and IT strategies in IT investment decision making for efficient cooperation among divisions and members involved in decision making process.

IT investment decision quality indicates 'effectiveness of IT investment decision making', which can be defined as follows, based on earlier study results: finding the possibilities for new business opportunities or more competitive advantage through IT investment or better understanding on risk factors in IT investment [13], [34],[35], [42].

Table 1.The Operational Definition of variable

\begin{tabular}{|l|l|l|l|}
\hline Variable & $\begin{array}{c}\text { Operational } \\
\text { definition }\end{array}$ & $\begin{array}{c}\text { Measureme } \\
\text { nt item }\end{array}$ & $\begin{array}{c}\text { Related } \\
\text { study }\end{array}$ \\
\hline IT & The degree & IT & Peterson, \\
Investment & of the & Investment & $2003 ;$ \\
Evaluation & organization & Evaluation & Van \\
Structure & of IT & Committee & Gremberge \\
(IES) & investment & & n et al., \\
& evaluation & & 2004; \\
& committee & & Van \\
& on the issues & & Gremberge \\
& when IT & & n and De \\
& investment & & Haes, \\
\hline
\end{tabular}

\begin{tabular}{|c|c|c|c|}
\hline & $\begin{array}{l}\text { decision } \\
\text { making }\end{array}$ & & $\begin{array}{l}2008 ; \\
\text { Weill and } \\
\text { Woodham, } \\
2002\end{array}$ \\
\hline $\begin{array}{l}\text { IT } \\
\text { Investment } \\
\text { Evaluation } \\
\text { Process } \\
\text { (IEP) }\end{array}$ & $\begin{array}{l}\text { The degree } \\
\text { of the } \\
\text { progress of } \\
\text { IT } \\
\text { investment } \\
\text { evaluation } \\
\text { process in IT } \\
\text { investment } \\
\text { decision } \\
\text { making }\end{array}$ & $\begin{array}{l}\text { IT } \\
\text { Investment } \\
\text { Evaluation } \\
\text { Process } \\
\text { Execution }\end{array}$ & $\begin{array}{l}\text { Peterson, } \\
2003 ; \\
\text { Van } \\
\text { Gremberge } \\
\text { n et al., } \\
2004 ; \\
\text { Van } \\
\text { Gremberge } \\
\text { n and De } \\
\text { Haes, } \\
2008 ; \\
\text { Weill and } \\
\text { Woodham, } \\
2002\end{array}$ \\
\hline $\begin{array}{l}\text { IT } \\
\text { Investment } \\
\text { Evaluation } \\
\text { Relational } \\
\text { Mechanism } \\
\text { (IEM) }\end{array}$ & $\begin{array}{l}\text { The decree } \\
\text { of the } \\
\text { communicati } \\
\text { on between } \\
\text { the } \\
\text { participating } \\
\text { divisions and } \\
\text { IT divisions } \\
\text { in IT } \\
\text { investment } \\
\text { decision } \\
\text { making }\end{array}$ & $\begin{array}{l}\text { Active } \\
\text { Communica } \\
\text { tion } \\
\text { between } \\
\text { Business } \\
\text { Member and } \\
\text { IT Member }\end{array}$ & $\begin{array}{l}\text { Peterson, } \\
2003 ; \\
\text { Reich and } \\
\text { Benbasat, } \\
\text { 1996; } \\
\text { Van } \\
\text { Gremberge } \\
\text { n et al., } \\
2004 ; \\
\text { Van } \\
\text { Gremberge } \\
\text { n and De } \\
\text { Haes, } \\
\text { 2008; } \\
\text { Weill and } \\
\text { Woodham, } \\
\text { 2002 }\end{array}$ \\
\hline $\begin{array}{l}\text { Business-IT } \\
\text { Strategic } \\
\text { Alignment } \\
\text { (BIA) }\end{array}$ & $\begin{array}{l}\text { The degree } \\
\text { of the } \\
\text { consideration } \\
\text { on the } \\
\text { relationship } \\
\text { between } \\
\text { business } \\
\text { strategies } \\
\text { and IT } \\
\text { strategies for } \\
\text { IT } \\
\text { investment }\end{array}$ & $\begin{array}{l}\text { Strategic } \\
\text { Harmony } \\
\text { between } \\
\text { Business } \\
\text { and IT on IT } \\
\text { Investment }\end{array}$ & $\begin{array}{l}\text { Chan et al., } \\
1997 ; \\
\text { Chan et al., } \\
2006 ; \\
\text { Luftman } \\
\text { and Brier, } \\
1999 ; \\
\text { Luftman, } \\
2000 ; \\
\text { Preston and } \\
\text { Karahanna, } \\
2008 \text {; } \\
\text { Reich and } \\
\text { Benbasat, } \\
2000\end{array}$ \\
\hline $\begin{array}{l}\text { IT } \\
\text { Investment } \\
\text { Decision } \\
\text { Quality } \\
\text { (IDQ) }\end{array}$ & $\begin{array}{l}\text { the degree of } \\
\text { which } \\
\text { decision } \\
\text { makers could } \\
\text { find out } \\
\text { business } \\
\text { opportunities } \\
\text { and risks; } \\
\text { and their } \\
\text { core } \\
\text { competences }\end{array}$ & $\begin{array}{l}\text { Rationality } \\
\text { of IT } \\
\text { Investment } \\
\text { Decision }\end{array}$ & $\begin{array}{l}\text { Dean and } \\
\text { Sharfman, } \\
\text { 1996; } \\
\text { Koo and } \\
\text { Lee, 2007; } \\
\text { Nutt, 1993; } \\
\text { Nutt, 1998; } \\
\text { Rodrigues } \\
\text { and } \\
\text { Hickson, } \\
1995\end{array}$ \\
\hline
\end{tabular}

\subsection{Sample and Data Collection Method}

The samples of this study are 252 companies that are in similar business scale and listed in KOSPI 200 and KOSDAQ. 
Unit of analysis is set to company level and the resources were collected from the directors of IT planning unit (or IT strategy planning departments) of the companies. The reason why the directors of IT planning departments were chosen as respondents for the survey lies in the expectations that they understand the overall workflow of IT investment as the mediators between IT divisions and other divisions and the members involved in IT investment decision making.

Response rate of the survey by phone, fax, email and visit was approximatly $60 \%$ (152 out of 252 companies responded) and the analysis was done on the final samples of 126 companies excluding the ones with incomplete responses.

Distribution of the companies by category is shown in Table 2 below. The distribution seems even in various business areas including finance, service, telecommunication, circulation/logistics and manufacturing. The survey results are shown in appendix 1 .

Table 2. Distribution of the Samples by Category

\begin{tabular}{|c|c|c|}
\hline Category & $\begin{array}{c}\text { Number of } \\
\text { Company }\end{array}$ & Rate \\
\hline Consumer products & 1 & $0.8 \%$ \\
Construction & 6 & $4.8 \%$ \\
Finance & 5 & $4.0 \%$ \\
Machinery & 6 & $4.8 \%$ \\
Insurance & 5 & $4.0 \%$ \\
Service & 6 & $4.8 \%$ \\
Transportation equipments & 5 & $4.0 \%$ \\
Circulation & 9 & $7.1 \%$ \\
Bank & 7 & $5.6 \%$ \\
Food/beverage & 11 & $8.7 \%$ \\
Medicine & 5 & $4.0 \%$
\end{tabular}

\begin{tabular}{|c|c|c|}
\hline Category & $\begin{array}{c}\text { Number of } \\
\text { Company }\end{array}$ & Rate \\
\hline Electric/electronics & 13 & $10.3 \%$ \\
Stocks & 10 & $7.9 \%$ \\
Steel/metal & 5 & $4.0 \%$ \\
Telecommunication & 3 & $2.4 \%$ \\
Chemical & 18 & $14.3 \%$ \\
IT service & 1 & $0.8 \%$ \\
Oil/gas & 3 & $2.4 \%$ \\
Transportation & 3 & $2.4 \%$ \\
Others & 4 & $3.2 \%$ \\
\hline Total & 126 & $100.0 \%$ \\
\hline
\end{tabular}

\section{ANALYSIS AND RESULTS}

\subsection{Validity Analysis and Cronbach's $\alpha$ on the Variables}

Validity is the degree of accuracy of the concept or property. It therefore indicates the degree of accuracy and validity of the conceptual and operational definition on the concept or property. Cronbach's $\alpha$ value on each variable using collected data shown in Table 3 shows 0.876 of IT investment evaluation structure; 0.807 of IT investment evaluation process; 0.900 of IT investment evaluation relational mechanism; 0.881 of business-IT strategic alignment; and 0.753 of IT investment decision quality. Reliabilities of all variables are over 0.7, suggesting very high reliability in application of the research model.

Table 3. Factor Analysis and Cronbach's $\alpha$ Value

\begin{tabular}{|c|c|c|c|c|c|c|c|}
\hline Construct & Item & 1 & 2 & 3 & 4 & 5 & Cronbach's $\alpha$ \\
\hline $\begin{array}{c}\text { IT Investment Evaluation } \\
\text { Structure }\end{array}$ & $\begin{array}{l}\text { IES_4 } \\
\text { IES_1 } \\
\text { IES_3 } \\
\text { IES_5 } \\
\text { IES_6 }\end{array}$ & $\begin{array}{l}0.815 \\
0.812 \\
0.734 \\
0.686 \\
0.620 \\
\end{array}$ & & & & & 0.876 \\
\hline IT Investment Evaluation Process & $\begin{array}{l}\text { IEP_2 } \\
\text { IEP_4 } \\
\text { IEP_3 }\end{array}$ & & $\begin{array}{l}0.822 \\
0.762 \\
0.710\end{array}$ & & & & 0.807 \\
\hline $\begin{array}{l}\text { IT Investment Evaluation } \\
\text { Relational Mechanism }\end{array}$ & $\begin{array}{l}\text { IEM_3 } \\
\text { IEM_1 } \\
\text { IEM_4 } \\
\text { IEM_2 }\end{array}$ & & & $\begin{array}{l}0.817 \\
0.783 \\
0.773 \\
0.706\end{array}$ & & & 0.900 \\
\hline Business-IT Strategic Alignment & $\begin{array}{l}\text { BIA_3 } \\
\text { BIA_4 } \\
\text { BIA_1 } \\
\text { BIA_2 }\end{array}$ & & & & $\begin{array}{l}0.866 \\
0.808 \\
0.733 \\
0.709\end{array}$ & & 0.881 \\
\hline IT Investment Decision Quality & $\begin{array}{l}\text { IDQ_2 } \\
\text { IDQ_1 } \\
\text { IDQ_3 }\end{array}$ & & & & & $\begin{array}{l}0.810 \\
0.707 \\
0.701\end{array}$ & 0.753 \\
\hline
\end{tabular}




\subsection{Hypotheses Test}

To test hypothesis 1,2 and 3 , effects of variables of IT investment evaluation structure, IT investment evaluation process and IT investment evaluation relational mechanism on business-IT strategic alignment were examined by multiple regression analysis.

$\mathrm{R}^{2}$ value was 0.400 , these antecedents explain approximatly $40 \%$ of the variance in business-IT strategic alignment. The Pvalue for overall appropriateness of the proposed model was $<0.001$ which was smaller than 0.01 , indicating that the model was suitable for significance level of 0.01 .

In examining significance of standardized coefficient for each independent variable, IT investment evaluation structure variable was significant of 0.05 level therefore hypothesis 1 was supported. IT investment evaluation process variable however was not significant therefore hypothesis 2 was rejected; IT investment evaluation mechanism variable was significant of 0.01 level, therefore hypothesis 3 was supported.

Effect of IT investment evaluation structure variable on business-IT strategic alignment as a dependent variable was 0.211(Standardized Coefficient); the effect of IT investment evaluation process was 0.127 ; and that of IT investment evaluation relational mechanism was 0.399 . The results show that IT investment evaluation relational mechanism affects business-IT strategic alignment more than IT investment evaluation structure.

Secondly, the effect of business-IT strategic alignment variable on IT investment decision quality variable was examined by regression analysis to test hypothesis $4 . R^{2}$ value was 0.113 , suggesting that business-IT strategic alignment variable could explain approximatly $11.3 \%$ the variance in IT investment decision quality. The $\mathrm{P}$-value for overall appropriateness of the proposed model was $<0.001$ which was smaller than 0.01, indicating that the model was suitable for significance level of 0.01 . In examining significance of standardized coefficient for each independent variable, business-IT strategic alignment was significant of 0.01 level therefore hypothesis 4 was supported. The effect of the independent variable, business-IT strategic alignment, on the dependent variable, IT investment decision quality, was 0.336 .

Figure 2 shows the effect of each variable in one form based on the research model of the verifications of hypothesis 1 4; it can be useful to identify relative weight of each variable.

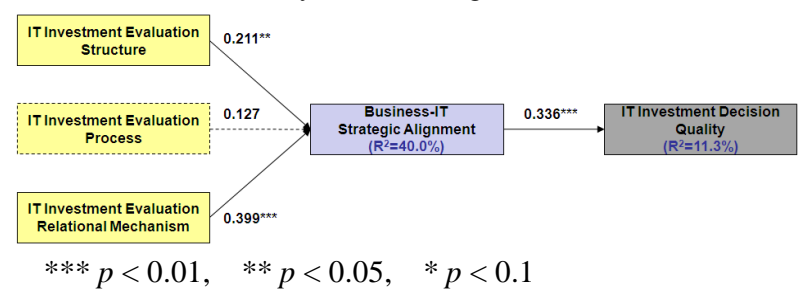

Fig. 2. Summary of the Results on the Research Model

The mediating effect of business-IT strategic alignment variable was measured by mediation regression analysis suggested by Baron and Kenny [3]. But the analysis was done limited to business-IT strategic alignment and IT investment evaluation structure and IT investment evaluation relational mechanism variable, which showed statistical significance.

The evaluation of mediating effects was performed by using the generally accepted technique in the social sciences proposed by Baron and Kenny [3]. This technique assesses mediating effects through a 3 -step regression analysis. The first step is to regress the mediator variable on the independent variable; the second step is regressing the dependent variable on the mediator; the third regressing the dependent variable on both the independent variable and the mediator [3]. If the results of these three regression analyses satisfy the following four conditions, mediating effects are confirmed: First, the first regression analysis must indicate that the independent variable has significant influence on the mediating variable. Second, the second regression analysis must indicate that the independent variable has significant influence on the dependent variable. Third, the mediating variable must have significant influence on the dependent variable. If these conditions all hold in the predicted direction, then the effect of the independent variable on the dependent variable must be greater in the second equation than in the third. Perfect mediation holds if the independent variable has no effect when the mediator is controlled [3]. By definition, in situations exhibiting a perfect (or full) mediation effect, a causal relationship between antecedents (e.g., IT investment evaluation structure) and a dependent variable (e.g., IT investment decision quality) can be explained only through a mediating variable (e.g., Business-IT Strategic Alignment). On the other hand, in some situations, a partial mediation effect supports the attestation of a causal relationship between antecedents and a dependent variable through both their direct relationship through the intervention or mediation of a mediating variable.

Table 4 shows the summary of the analysis results on the mediating effect of business-IT strategic alignment variable. The results show that business-IT strategic alignment variable shows partial mediating effect between IT investment evaluation structure and IT investment decision quality variable; and no mediating effect between IT investment evaluation relational mechanism and IT investment decision quality variable. It suggests that IT investment evaluation relational mechanism variable can directly explain IT investment decision quality.

Table 4. Analysis on Mediating Effect of Business-IT Strategic Alignment Variable

\begin{tabular}{|c|c|c|c|c|}
\hline \multirow{2}{*}{ Step } & \multirow{2}{*}{$\begin{array}{c}\text { Dependent } \\
\text { variable }\end{array}$} & \multicolumn{2}{|c|}{ Independent variable } & \multirow{2}{*}{$\mathbf{R}^{2}$} \\
\cline { 3 - 4 } & Variable & Beta & \\
\hline 1.1 & Alignment & Structure & $0.504 * * *$ & 0.254 \\
\hline 1.2 & Quality & Structure & $0.430 * * *$ & 0.185 \\
\hline 1.3 & Quality & Structure & $0.349 * * *$ & 0.204 \\
\hline & & Alignment & $0.160 *$ & \\
\hline 2.1 & Alignment & Mechanism & $0.586 * * *$ & 0.344 \\
\hline 2.2 & Quality & Mechanism & $0.552 * * *$ & 0.305 \\
\hline 2.3 & Quality & Mechanism & $0.542^{* * *}$ & 0.305 \\
\hline & & Alignment & 0.018 & \\
\hline & & $* * * p<0.01$, & $* * p<0.05, * p<0.1$ \\
\hline
\end{tabular}

Revised research model expected through the results of analysis on mediating effect of business-IT strategic alignment variable can be demonstrated as Figure 3. 


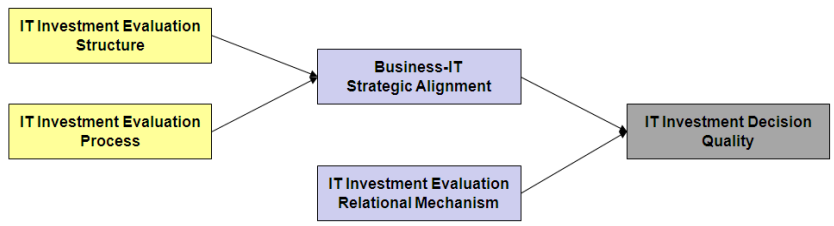

Fig. 3. Revised Research Model Expected Through the Results of Analysis on Mediating Effect

\section{CONCLUSION}

\subsection{Conclusion and Implications}

This study is to provide a proof of the effect of IT investment governance on the quality of IT investment decision making by applying IT governance concept to IT investment decision making. Total of 126 Korean firms were responded after final verification and the hypotheses were analyzed; it was confirmed that IT investment governance made positive effect on the quality of IT investment decision making. Especially IT investment evaluation structure and IT investment evaluation relational mechanism make positive effect on business-IT strategic alignment for IT investment strategies in IT investment decision making. It implies that proper IT investment evaluation organizations or committees and clear role and responsibility arrangements for the members bring out more positive and effective business-IT relationship. In addition, efficient communication among members of the related divisions and IT divisions involved in IT investment decision making is helpful for efficient cooperation/agreement between business and IT division.

However IT investment evaluation process doesn't affect business-IT strategic alignment in IT investment decision making. The reason can be explained as follows: it is possible that the official IT investment evaluation procedure or methodology were not recognized as the formalized process when decision making is preceded. It means that decision making through the prescribed procedure in IT investment evaluation committee may not be considered as IT investment evaluation process but as part of IT management process in terms of overall company management.

Business-IT strategic alignment makes positive effect on the quality of IT investment decision making. Strategic relationship and mutual agreement between the related division and IT division involved in IT investment decision making bring more reasonable IT investment decision making.

However the mediation regression analysis on business-IT strategic alignment by Baron and Kenny [3] shows that business-IT strategic alignment variable has partial mediating effect between IT investment evaluation structure and IT investment decision quality variable. This implies that a factor that affects the quality of IT investment decision making may exist apart from factors of the structure and organization of IT investment evaluation committee. Business-IT strategic alignment variable shows no mediating effect between IT investment evaluation relational mechanism and IT investment decision quality variable, suggesting that it can directly explain IT investment decision quality of IT investment evaluation relational mechanism variable.
Implications of the study results are as follows: first, IT investment evaluation structure, workflow and IT investment evaluation relational mechanism are very important for efficient IT investment decision making. Especially in establishing an organization of IT investment decision making, clear arrangement of roles and responsibilities among the members of the related division and IT division is important to realize balance and harmony.

Yet, high level of strategic alignment between the divisions brings the most effective decision making. As shown in the analysis results, IT investment evaluation relational mechanism(standardized coefficient 0.399) generates more effect than IT investment evaluation structure(standardized coefficient 0.211). Therefore the level of strategic alignment between the related division and IT division should be raised when decision making; furthermore, the level of business-IT strategic alignment throughout the company should be raised. For timely and wise IT investment decision making, communication between the members of the related division and IT division should precede when decision making.

\subsection{Limitations and Further Study Directions}

Research contributions for researchers in terms of academic aspect of this study are as follows: first, the survey of this study provides proof while existing studies on IT governance are mostly conceptual and focus on case studies. This study is also significant that it explores and applies IT Governance concept to IT investment decision making.

Research contributions for practitioners in terms of practice are as follows: considering that IT investment ultimately affects the business showings, companies can create more positive effect to secure superior places in the market by making timely, effective IT investment. The important thing is to make reasonable, proper decisions; identifying important factors and focus points can be helpful to make wise IT investment decisions. This study contributes to identify main factors for reasonable, effective IT investment decision making and provides proper guideline for decision making to bring positive effect for securing superior place in the market.

Companies with well-established IT governance system show better results from IT investment [55]; therefore great IT Investment governance system will bring wise IT investment decisions, which can also lead to better IT investment results.

This study however has limitations. The study was conducted under the situation of almost no development of IT governance-related measurement; therefore it was difficult in the beginning of the study. Further development of IT governance-related measurement is needed. Development of various measurement tools for accurate measurement of IT Investment governance in IT investment decision making and more elaborate tools for IT investment evaluation processes in the hypotheses rejected in this study is needed. In addition, development of more elaborate measurement of IT investment decision quality for effective IT investment decision making is needed. 


\section{APPENDIX}

Appendix 1. Survey Results

\begin{tabular}{|c|c|c|}
\hline \multicolumn{3}{|c|}{ Distribution of IT investment budget to gross income } \\
\hline IT investment budget to gross income (\%) & Frequency & Ratio \\
\hline $0.1 \sim 0.5 \%$ & 111 & $88.1 \%$ \\
\hline $0.6 \% \sim 1.0 \%$ & 12 & $9.5 \%$ \\
\hline $1.1 \% \sim 2.0 \%$ & 2 & $1.6 \%$ \\
\hline $2.1 \% \sim 3.0 \%$ & 0 & $0.0 \%$ \\
\hline $3.1 \% \sim 4.0 \%$ & 0 & $0.0 \%$ \\
\hline Over $4.1 \%$ & 1 & $0.8 \%$ \\
\hline Total & 126 & $100.0 \%$ \\
\hline \multicolumn{3}{|c|}{ Distribution of IT spending to revenue by IT investment committee } \\
\hline Distribution of IT spending to revenue (KRW) & Frequency & Ratio \\
\hline Over 0.1 billion & 19 & $15.1 \%$ \\
\hline Over 0.5 billion & 93 & $73.8 \%$ \\
\hline Over 1 billion & 11 & $8.7 \%$ \\
\hline Over 3 billion & 3 & $2.4 \%$ \\
\hline Total & 126 & $100.0 \%$ \\
\hline \multicolumn{3}{|c|}{ IT investment committee participants population } \\
\hline The average number of participant & Frequency & Ratio \\
\hline Less than 3 & 16 & $12.7 \%$ \\
\hline 3 to 5 & 90 & $71.4 \%$ \\
\hline 5 to 10 & 18 & $14.3 \%$ \\
\hline 10 to 15 & 2 & $1.6 \%$ \\
\hline Total & 126 & $100.0 \%$ \\
\hline \multicolumn{3}{|c|}{ IT investment committee principals population (multiple response, sample size=126) } \\
\hline The average number of participant & Frequency & Ratio \\
\hline CEO & 79 & $62.7 \%$ \\
\hline $\mathrm{CIO}$ & 103 & $81.7 \%$ \\
\hline Each department manager & 67 & $53.2 \%$ \\
\hline Each IT planning department director & 72 & $57.1 \%$ \\
\hline C-Level official & 5 & $4.0 \%$ \\
\hline
\end{tabular}

\section{REFERENCES}

[1] F. Bannister and D. Remenyi, "Value proposition in IT investment decisions," The Electronic Journal of Information Systems Evaluation, vol. 4, no. 1, 1999.

[2] F. Bannister and D. Remenyi, "Acts of faith: instinct, value and IT investment decisions," Journal of Information Technology, vol. 15, no. 3, 2000, pp. 231-241.

[3] R. Baron and D. Kenny, "The moderator-mediator variable distinction in social psychological research: Conceptual, strategic, and statistical considerations," Journal of personality and social psychology, vol. 51, no. 6, 1986, pp. 1173-1182.

[4] S. Buckby, Board review of IT governance in Australian universities, Queensland University of Technology, Australia, 2008.

[5] J. Burn and C. Szeto, "A comparison of the views of business and IT management on success factors for strategic alignment," Information \& Management, vol. 37, no. 4, 2000, pp. 197-216.

[6] J. Coughlan, M. Lycett, and R. Macredie, "Understanding the business-IT relationship," International Journal of Information Management, vol. 25, no. 4, 2005, pp. 303-319.

[7] M. C. Cronk and E. P. Fitzgerald, "Constructing a theory of
'IS business value' from the literature." Electronic Journal of Business Research Methods, vol. 1, no. 1, 2002, pp. 1117.

[8] A. Croteau and F. Bergeron, "An information technology trilogy: business strategy, technological deployment and organizational performance," Journal of Strategic Information Systems, vol. 10, no. 2, 2001, pp. 77-99.

[9] B. Cumps, S. Viaene, G. Dedene, and J. Vandenbulcke, "An empirical study on business/ict alignment in european organizations," Proc. 39th Hawaii International Conference on System Sciences, 2006.

[10] L. Dadayan, "Measuring Return on Government IT Investments," Proc. 13th European Conference on Information Technology Evaluation, September 2006.

[11] S. De Haes and W. Van Grembergen, "IT Governance and its Mechanisms," Information Systems Control Journal, vol. 1, 2004, pp. 27-33.

[12] S. De Haes and W. Van Grembergen, "IT governance structures, processes and relational mechanisms: Achieving IT/Business alignment in a major Belgian financial group," Proc. 38th Hawaii International Conference on System Sciences, 2005.

[13] J. Dean Jr. and M. Sharfman, "Does decision process matter? A study of strategic decision-making 
effectiveness," The Academy of Management Journal, vol. 39, no. 2, 1996, pp. 368-396.

[14] J. Dedrick, V. Gurbaxani, and K. Kraemer, "Information technology and economic performance: A critical review of the empirical evidence," ACM Computing Surveys (CSUR), vol. 35, no. 1, 2003, pp. 1-28.

[15] J. Duffy, "IT/Business alignment: Is it an option or is it mandatory?," IDC document \#26831, 2002a.

[16] J. Duffy, "IT Governance and business value part 1: IT Governance-An issue of critical importance," IDC document \#27291, 2002b.

[17] M. Earl, Management strategies for information technology, Prentice-Hall, Inc., Upper Saddle River, NJ, USA. 1989.

[18] R. Feurer, K. Chaharbaghi, M. Weber, and J. Wargin, "Aligning strategies, processes, and IT: A case study," Information Systems Management, vol. 17, no. 1, 2000, pp. 23-34.

[19] Gartner, "Gartner Says IT Spending to rebound in 2010 with 3.3 Percent Growth After Worst Year Ever in 2009," 2009, Available at: http://www.gartner.com/it/page.jsp?id=1209913

[20] E. Guldentops, "IT Governance: Part and Parcel of Corporate Governance, CIO Summit," Procs. The European Financial Management \& Marketing Conference, Brussels, 2003.

[21] J. Henderson and N. Venkatraman, "Strategic alignment: Leveraging information technology for transforming organizations," IBM systems Journal, vol. 32, no. 1, 1993, pp. 4-16.

[22] ITGI., Board briefing on IT Governance, 2001.

[23] P. G. W. Keen, Every Manager's Guide to Information Technology: A Glossary of Key Terms and Concepts of Today's Leader (2 ed.), Harvard Business School Press, Cambridge, Massachusetts, 1995.

[24] B. J. Koo and K. H. Lee, "Analysing Decision Making Factors of IT Investment Projects," Information Systems Review, vol. 9, no. 1, 2007, pp. 161-189.

[25] C. Lee, J. Lee, and D. Jang, "IT Governance-Based IT Strategy and Management: Literature Review and Future Research Directions," Proc. 35th Conference on The Korea Society of Management Information Systems, 2006, pp. 853-863

[26] J. Lee and C. Lee, IT Governance-Based IT Strategy and Management: Literature Review and Future Research Directions Information Technology Governance and Service Management: Frameworks and Adaptations (pp. 44-62), Information Science Reference (an imprint of IGI Global), Hershey PA, 2008.

[27] J. B. Lee, Y. J. Hong, and Y. H. Chang, "A Case Study on the Correlation between the Quantitative and the Qualitative Evaluation of IT Investment Performance," Information Systems Review, vol. 9, no. 2, 2007, pp. 149-168.

[28] C. Lin, G. Pervan, and D. McDermid, "IS/IT investment evaluation and benefits realization issues in Australia," Journal of Research and Practice in Information Technology, vol. 37, no. 3, 2005, pp. 235-251.

[29] J. Luftman, "Assessing business-IT alignment maturity,"
Communications of AIS, vol. 4, no.14, 2000.

[30] J. Luftman and T. Brier, "Achieving and sustaining business-IT alignment," California Management Review, vol. 42, no.1, 1999, pp. 109-122.

[31] R. Maes, "Reconsidering information management through a generic framework," PrimaVera working Paper, Amsterdam, 1999, pp. 99-15.

[32] D. Mirtidis and V. Serafeimidis, "Evaluating information technology investments in Greece," Proc. 1st European Conference on IT Investment Evaluation, Henley, September 1994.

[33] R. Morgan, "Information technology: second-class citizen or strategy partner," Journal of Business Strategy, vol. 24, no. 6, 2003, pp. 38-45.

[34] P. Nutt, "The formulation processes and tactics used in organizational decision making," Organization Science, vol. 4, no. 2, 1993, pp. 226-251.

[35] P. Nutt, "Framing strategic decisions," Organization Science, vol. 9, no. 2, 1998, pp. 195-216.

[36] N. Patel, An emerging strategy for e-business IT Governance. In W. Van Grembergen (Ed.), Strategies for information technology governance (pp. 81-97), Idea Group Publishing, 2004.

[37] R. R. Peterson, Information strategies and tactics for information technology governance. In W. Van Grembergen (Ed.), Strategies for information technology governance, Idea Group Publishing, Hershey, PA, 2003.

[38] R. R. Peterson, "Configurations and coordination for global information technology governance designs in a traditional European context," Proc. 34th Hawaii International Conference on System Sciences, 2004.

[39] Y. Pollalis, "Patterns of co-alignment in informationintensive organizations: business performance through integration strategies," International Journal of Information Management, vol. 23, no. 6, 2003, pp. 469492.

[40] C. Ranganathan and V. Sethi, "Rationality in strategic information technology decisions: The impact of shared domain knowledge and IT unit structure," Decision Sciences, vol. 33, no. 1, 2002, pp. 59-86.

[41] P. Ribbers, R. Peterson, and M. Parker, "Designing information technology governance processes: Diagnosing contemporary practices and competing theories," Proc. 35th Hawaii International Conference on Systems Sciences, 2002.

[42] S. Rodrigues and D. Hickson, "Success in decision making: different organizations, differing reasons for success," Journal of Management Studies, vol. 32, no. 5, 1995, pp. 655-678.

[43] V. Sambamurthy and R. Zmud, "Arrangements for information technology governance: A theory of multiple contingencies," MIS Quarterly, vol. 23, no. 2, 1999, pp. 261-290.

[44] M. J. Schniederjans, J. L. Hamaker, and A. M. Schniederjans, Information Technology Investment: Decision-Making Methodology, World Scientific Publishing Company River Edge, New Jersey, 2004.

[45] Standish group, Chaos, 1995.

[46] T. Smaczny, "Is an alignment between business and 
information technology the appropriate paradigm to manage IT in today's organisations?," Management Decision, vol. 39, no. 10, 2001, pp. 797-802.

[47] T. Teo and J. Ang, "Critical success factors in the alignment of IS plans with business plans," International Journal of Information Management, vol. 19, no. 2, 1999, pp. 173-185.

[48] W. Van Grembergen, Strategies for information technology governance, Idea Group Publishing Inc., Hershey, PA, 2004.

[49] W. Van Grembergen and S. De Haes, Implementing Information Technology Governance: Models, Practices and Cases, IGI Publishing, Hershey, PA, USA, 2008.

[50] W. Van Grembergen, S. De Haes, and E. Guldentops, Structures, processes and relational mechanisms for information technology governance: Theories and practices. In W. Van Grembergen (Ed.), Strategies for Information Technology Governance, Idea Group Publishing, 2004.

[51] W. Van Grembergen and R. Saull, "Aligning business and Information Technology through the balanced scorecard at a major Canadian financial group: Its status measured with an IT BSC Maturity Model," Proc. 34th Hawaii International Conference on System Sciences, 2001.

[52] W. Van Grembergen, R. Saull, and S. De Haes, Linking the IT balanced scorecard to the business objectives at a major Canadian financial group. In W. Van Grembergen (Ed.), Strategies for information technology governance (pp. 129), Idea Group Publishing, Hershey, PA, 2003.

[53] P. Weill and M. Broadbent, Leveraging the new infrastructure: How market leaders capitalize on information technology, Harvard Business School Press, 1998.

[54] P. Weill and M. Olson, "Managing investment in information technology: mini case examples and implications," MIS Quarterly, vol. 13, no. 1, 1989, pp. 317.

[55] P. Weill and J. W. Ross, IT governance: How top performers manage IT decision rights for superior results, Harvard Business School Press, Cambridge, MA, 2004.

[56] P. Weill and R. Woodham, Don't just lead, govern: Implementing effective IT governance, Center for Information Systems Research, Massachusetts Institute of Technology, CISR Working Paper (No.326), 2002.

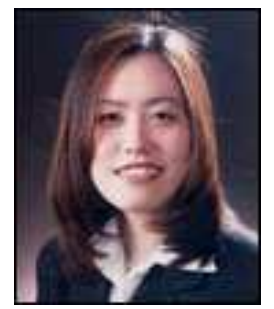

\section{Ju-Yeon Ham}

She is a Ph.D candidate from the Korea University Business School, Seoul, Korea. She received the M.Sci in information systems from Graduate School of Information, Yonsei University, Seoul, Korea. Her main research interests include MOT and IT Governance.

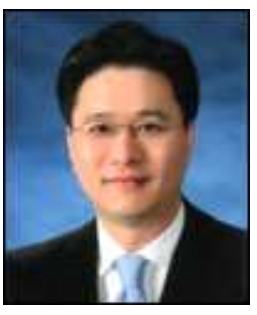

Jung-Hoon Lee

$\mathrm{He}$ is an associate professor at the Graduate School of Information, Yonsei University, Seoul, Korea. He received B.Eng/MSci in Electronic Engineering/Information Systems Engineering, MSc Information Systems from University of Manchester and London School of Economics, and Ph.D. from Manufacturing Engineering and Management from Institute for Manufacturing, University of Cambridge, U.K.. His main research interests include IT Governance, Performance Measurement in IT, System Dynamics, Multi agent systems modeling and simulation, and Information System Intelligence.

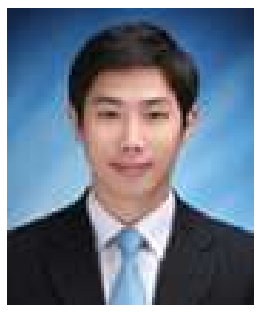

Hyeok-Jun Woo

$\mathrm{He}$ is a M.Sci candidate from Graduate School of Information, Yonsei University, Seoul, Korea. He received the B.A in arts from University of Hanyang, Seoul, Korea. Currently, he is participating in the 'u-Service development for u-City' project of Ministry of Land, Transport and Maritime Affairs, and ' $u$ Seoul development' project. His main research interests include u-Service, NSD, MOT, and social informatics. 